\title{
Development and Testing of an Ammonia Removal Unit from the Exhaust Gas of a Manure Drying System
}

\author{
A.E. Ghaly and K.N. MacDonald \\ Department of Process Engineering and Applied Science, Dalhousie University, Halifax, Nova Scotia, Canada
}

Received 2013-03-05, Revised 2013-03-27; Accepted 2013-03-27

\begin{abstract}
The storage and handling of animal wastes is one of the main sources of ammonia gas emissions. Ammonia gas has a distinct, unpleasant odor and can become detrimental to the health of humans and animals at high concentrations. Ammonia emissions are of particular concern in manure drying systems, where large losses of nitrogen, in the form of ammonia can cause air quality concerns. The aim of this study was to develop an ammonia removal system for a poultry manure drying system. The thin layer drying of poultry manure in 1-3 cm thick layers resulted in effective sterilization; with the removal of 99.44$99.56 \%$ of total bacterial count, 88.51-93.705 of yeast and mold cells, 99.13-99.565 of E.coli cells, and complete removal of Salmonellae. The drying of poultry manure resulted in a large loss of nitrogen, through ammonia loss in the exhaust gasses. The use of a water scrubber resulted in a 75-99\% removal of ammonia gas from the exhaust gases. The absorption of ammonia into the scrubber's water resulted in an increase in $\mathrm{pH}$, which subsequently fell as the drying process finished, and ammonia emission decreased. The heated air drying of poultry manure, with the use of an ammonia removal system proved effective in reducing the odor intensity and offensiveness of the poultry manure drying process, resulting in increased air quality. While producing a high value product.
\end{abstract}

Keywords: Ammonia, Manure, Scrubber, Thin layer drying, Bacteria, Odor, pH

\section{INTRODUCTION}

Ammonia gas is a severe respiratory tract and ocular irritant in humans. The severity of ocular effects following ammonia gas exposure increase with dose and duration (Table 1). Symptoms typically include inflammation and lacrimation, swelling of the eyelids, blurred vision, corneal abrasions, sustained corneal damage and blindness. Skin is also sensitive to gaseous and aqueous ammonia. Vapor concentrations of 10,000 ppm are mildly irritating to moist skin, whereas exposure to concentrations between 20,000 and 30,000 ppm may produce chemical burns with blistering and tissue death. Permanent scarring of the skin may result. Occupational Safety and Health Administration standards specify a permissible exposure limit of $50 \mathrm{ppm}(35 \mathrm{mg} / \mathrm{m} 3)$ for an 8 hour period (ASTDR, 2002).

Ammonia is a colorless gas that is lighter than air and has a unique odor. Natural sources of ammonia include emissions from (a) livestock, primarily during the decomposition of animal excreta, (b) soil, resulting from the decay of organic materials, (c) forest fires and slash burning and (d) volcanic eruptions. Ammonia is also released by industrial processes, such as petrochemical refining, metal and pulp and paper manufacturing, food preparation (Chung et al., 1997) and from wastewater treatment plants (ASTDR, 2002; Anderson et al., 2003). Commercially, ammonia is used in the production of fertilizers, plastics, synthetic fibers, resins and explosives.

Corresponding Author: A.E. Ghaly, Department of Process Engineering and Applied Science, Dalhousie University, Halifax, Nova Scotia, Canada 
Table 1. Physiological effects of ammonia inhalation (Seidel, 2004; and ASTDR, 2002).

\begin{tabular}{ll}
\hline Concentration (ppm) & Effects \\
\hline $20-50$ & Perceptible odor \\
$40-100$ & Immediate upper respiratory \\
& tract irritation \\
$400-700$ & Severe respiratory irritation; potential \\
& for permanent damage \\
1,700 & Convulsive coughing, bronchial \\
& spasms, pulmonary \\
& edema; potentially fatal \\
$5,000-10,000$ & Death by suffocation \\
\hline
\end{tabular}

Volatization of ammonia typically occurs as a result of fertiliser and manure applications, spills or leaks from manure storage and animal production facilities. However, emission of ammonia from livestock is one of the largest contributors to atmospheric ammonia (Anderson et al., 2003; Heinsohn et al., 2000). Some characteristics of ammonia are presented in Table 2.

Various physical, chemical and biological processes have been used to remove ammonia from gaseous effluents including: adsorption, absorption, incineration and biofiltration (Chung et al., 1997). Adsorption is a process whereby gaseous components are removed from and effluent gas stream by adhering to the surface of a solid medium. The most common media used in industry are activated carbon, silica gel, activated alumina and zeolites. In gas absorption, the effluent gas stream is allowed to come into contact with a liquid and pollutants are removed from the gas stream by dissolving in the liquid. A wet scrubber is the generic name of an air pollution controldevice that uses the process of absorption to separate the pollutant from a process gas stream. Vapor incineration is a process involving controlled burning at high temperatures in which oxygen in the air oxidizes waste molecules. In biofiltration, moist biofilms are attached to a porous media in a packed bed bioreactor. Media typically used in biofilters included compost, soil or peat that has been mixed with a bulking agent. As the contaminated gas stream is passed through the biofilter, the pollutants are degraded by the microorganisms (Heinsohn et al., 2000).

Poultry manure can be dried using solar energy (Ghaly and MacDonald, 2012a) and used as fertilizer (Ghaly and Alhattab, 2012) or animal feed (Ghaly and MacDonald, 2012b; Thomas et al., 1972; Alam et al., 2008). Drying refers to the removal of moisture from the manure so that it is near equilibrium with atmospheric air. By drying, the rate of deterioration from chemical and microbial activities is minimized (Ghaly and MacDonald, 2012b).
Table 2. Physical and chemical properties of ammonia (Seidel, 2004; ASTDR, 2002).

\begin{tabular}{ll}
\hline Property & Value \\
\hline Molecular weight & $17.032 \mathrm{~g} / \mathrm{mole}$ \\
Boiling point $(1 \mathrm{~atm})$ & $-33.35^{\circ} \mathrm{C}$ \\
Melting point & $-77.70^{\circ} \mathrm{C}$ \\
Diffusivity $\left(25^{\circ} \mathrm{C}\right)$ & $1.7-2.3 \times 10^{-5} \mathrm{~cm}^{2} / \mathrm{s}$ \\
Critical temperature & $133.0^{\circ} \mathrm{C}$ \\
Critical pressure & $11,425 \mathrm{kPa}$ \\
Density & $0.7708 \mathrm{~g} / \mathrm{L}$ \\
pKa $\left(25^{\circ} \mathrm{C}\right)$ & 9.25 \\
Specific heat & \\
$0^{\circ} \mathrm{C}$ & $2097.2 \mathrm{~J} / \mathrm{kg} \cdot \mathrm{K}$ \\
$100^{\circ} \mathrm{C}$ & $2226.2 \mathrm{~J} / \mathrm{kg} \cdot \mathrm{K}$ \\
$200^{\circ} \mathrm{C}$ & $2105.6 \mathrm{~J} / \mathrm{kg} \cdot \mathrm{K}$ \\
$\mathrm{Heat}$ of formation of gas, $\Delta \mathrm{H}_{\mathrm{f}}$ & \\
$0 \mathrm{~K}$ & $-39,222 \mathrm{~kJ} / \mathrm{mol}$ \\
$298 \mathrm{~K}$ & $-46,222 \mathrm{~kJ} / \mathrm{mol}$ \\
$\mathrm{Solubility} \mathrm{in} \mathrm{water,} \mathrm{wt} \%$ & \\
$0^{\circ} \mathrm{C}$ & $42.8 \%$ \\
$15^{\circ} \mathrm{C}$ & $38 \%$ \\
$20^{\circ} \mathrm{C}$ & $33.1 \%$ \\
$30^{\circ} \mathrm{C}$ & $28 \%$ \\
$40^{\circ} \mathrm{C}$ & $23.4 \%$ \\
$50^{\circ} \mathrm{C}$ & $18 \%$ \\
$60^{\circ} \mathrm{C}$ & $14.1 \%$ \\
$\mathrm{Specific}$ gravity & \\
$-40^{\circ} \mathrm{C}$ & 0.690 \\
&
\end{tabular}

Drying also removes manure stickiness hence allowing for easier handling (Bernhart and Fasina, 2009). However, the drying process resulted in a total nitrogen reduction of $55 \%$, most of which was lost in the form of ammonia with the exhaust gasses causing significant air pollution and health problems (Ghaly and MacDonald, 2012a). The aim of this study was to develop and evaluate an efficient system for the removal of ammonia from the exhaust gas of the manure dryer.

\section{POULTRY MANURE DRYER}

A manure drying system was designed, constructed and used to dry and sterilize poultry manure for use as animal feed (Fig. 1). The system consisted of a temperature controlled chamber with an air heating and circulating unit, a manure drying unit, an exhaust unit and a data acquisition and control unit.

The temperature controlled chamber was built of wood and was completely insulated with fiberglass insulation material $\left(\mathrm{R}=3.4 \mathrm{~m}^{2} \mathrm{sK} / \mathrm{J}\right)$ placed between two $2.2 \mathrm{~cm}$ thick layers of plywood. The temperature of the chamber was controlled and it represented the hourly outdoor temperature for 365 days. 

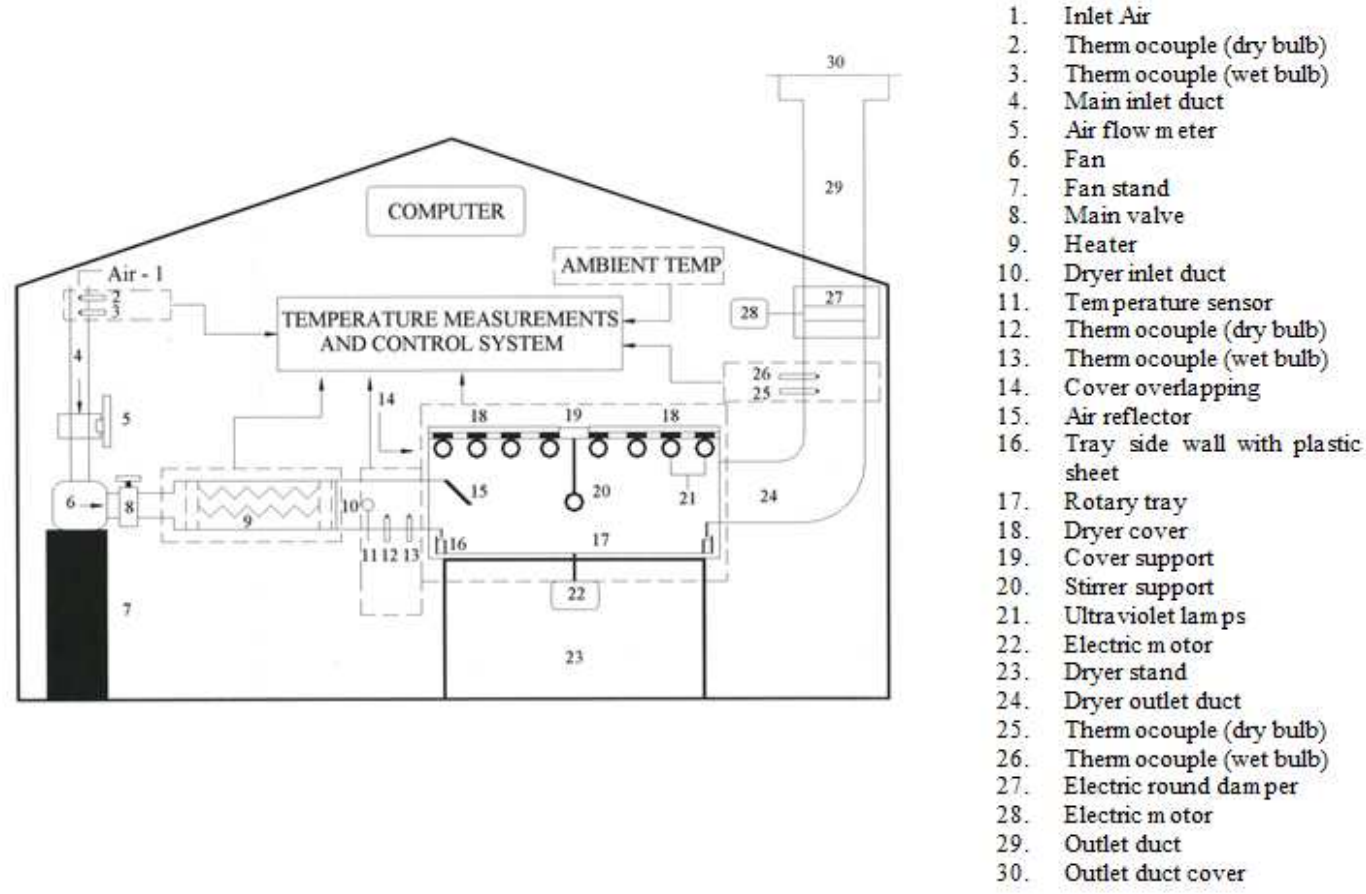

Figure 1. A schematic representation of the manure drying system.

The manure drying unit consisted of a $100 \mathrm{~cm}$ long $\mathrm{x}$ $100 \mathrm{~cm}$ wide $\times 35 \mathrm{~cm}$ deep box made of aluminum sheet metal. The inlet and outlet ducts were $40 \times 10 \mathrm{~cm}$ to allow for good air distribution in the box. A reflector (40 x $20 \mathrm{~cm}$ ) was used by the inlet duct to reflect the heat onto the manure surface. The dryer cover was made of a stainless steel support beam $(100 \times 5 \times 5 \mathrm{~cm})$ with two cover parts hinged to the beam using $100 \mathrm{~cm}$ long piano hinges secured by nine screws on both sides (Fig. 2). A $99 \mathrm{~cm}$ diameter rotary tray with an $8 \mathrm{~cm}$ side wall was constructed from aluminum sheet metal and placed above the bottom base of the dryer. A scraper was put on the side of the wall of the tray, and it was lined with plastic $(2 \mathrm{~cm}$ thick) so that manure would not stick to the aluminum during drying. The bottom of the circular tray was lined with stainless steel, so that cleaning would be easier. The tray was rotated at 1.6 rpm using a $450 \mathrm{~W}$ electric motor (Sigma- Cat. No. 20-3424SG-24303 - 115 volts - 0.35 amp., Sigma Aldrich, St. Louis, Missouri, USA). The rotary tray was fitted with eight copper-constantan thermocouples (Omega Type-T Cat. No. 06907-0047, Omega Engineering, Laval, Quebec, Canada) for measuring the manure temperature. The thermocouples were mounted on four aluminum supports that were fixed in the corners of the rectangular drying unit and extended over the rotating tray. The copper tubes were attached to aluminum supports to ensure that the thermocouples remained at a distance of $0.2 \mathrm{~cm}$ from the rotating tray. The whole drying unit was mounted on a stainless steel stand $(100 \times 100 \times 40 \mathrm{~cm}$ in height). The drying unit was completely insulated with thick vapor seal duct insulation (Fiberglass Canada- $\mathrm{R}=4.16 \mathrm{~m}^{2} \mathrm{~s} \mathrm{~K} / \mathrm{J}$ ).

The manure was mixed constantly using a mechanical motor stirrer. The stirrer was made of a stainless steel rod $(2.5 \mathrm{~cm}$ in diameter and $60 \mathrm{~cm}$ in length). Finger-like spikes $10 \mathrm{~cm}$ in length were attached to the rod. The spikes were separated by $3 \mathrm{~cm}$ spaces and arranged so that they were perpendicular to each other. One end of the rod was supported by a vertical rod fixed to the center of the dryer top. The other end of the rod has a 20 tooth sprocket. The stirrer was rotated by a $1 / 8 \mathrm{Hp}$ variable speed electric motor, which was mounted to the support stand under the dryer. The shaft of the motor has a 14 tooth sprocket mounted and connected to the sprocket on the stirrer by a $20 \mathrm{~cm}$ long chain. The motor was connected to a speed measurement and control unit (GKH Heller HST20 series stir testers, Glas Col, Terra Haute, Illinois, USA), so that the speed could becorrectly controlled. 

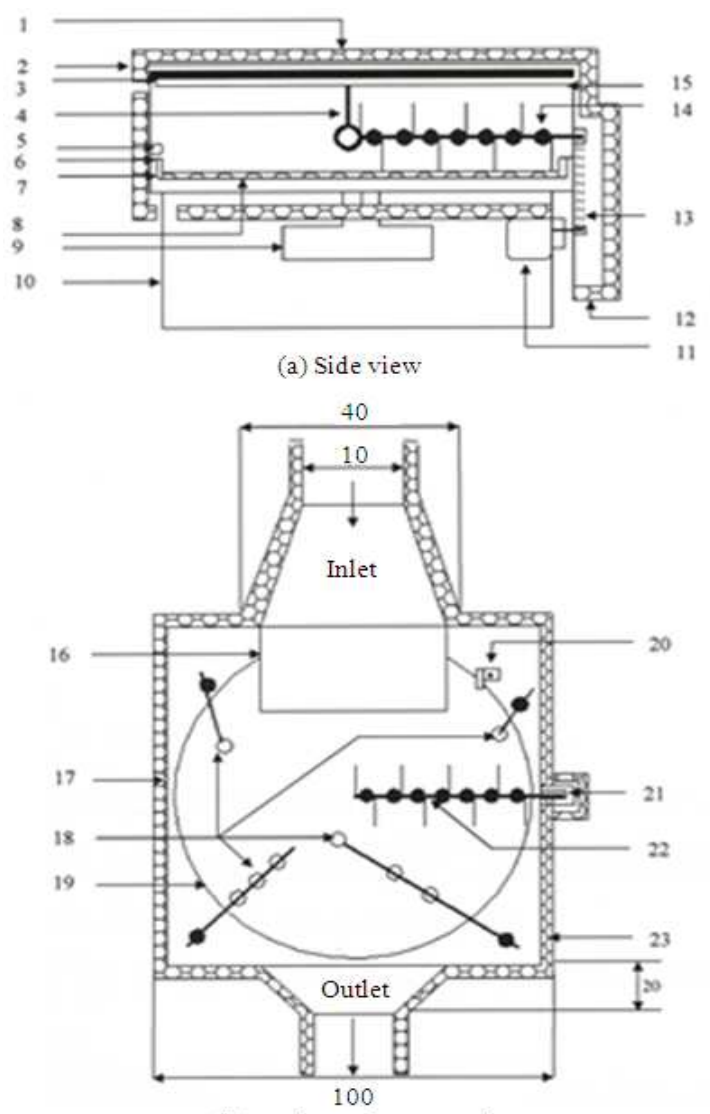

(b) Horizontal cross section
1. Dryer cover

2. Cover overlapping

3. Cover sides support

4. Stirer support

5. Micro switch

6. Tray overlapping

7. Side wall of tray

8. Manure

9. Electric motor (tray)

10. Rectangular stand

11. Electric motor (stirrer)

12. Chain cover

13. Chain

14. Rotary stirre

15. Ultraviolet unit

16. Air reflector

17. Dryer base

18. Thermocouples

19. Rotary tray

20. Scraper

21. Gear sprocket cover

22. Stirrer

23. Insulation material

Figure 2. Manure drying unit.

The inlet air to the dryer was heated using an electric heater $(3.0 \mathrm{~kW})$ to simulate the outlet air of a solar collector the air being heated was introduced to the heater by a blower (Engenair-Model No. R4110-2-220 volts-4.9 amps, Regenair, Rosemere, Quebec, Canada) which brought the air in through a $5 \mathrm{~cm}$ diameter inlet duct. The blower was operated using a $1.5 \mathrm{Hp}, 3$ phase electric motor. The air flow was controlled by a $5 \mathrm{~cm}$ diameter gate valve located before the heater. The flow rate was measured using a FLT-type "Flow Cell Bypass Flowmeter", which had a 0.012 to $0.05 \mathrm{~m}^{3} / \mathrm{s}$ range.

The exhaust system consisted of an L shaped outlet duct fitted with a round mechanical damper. The horizontal part of the exhaust system was attached at one end $(40 \times 10 \mathrm{~cm})$ to the dryer, while the other end $(10 \times 10$ $\mathrm{cm})$ was connected to the $10 \mathrm{~cm}$ diameter vertical cylinder. The vertical cylinder took the exhaust air out of the chamber and into the atmosphere. The vertical cylinder was $320 \mathrm{~cm}$ in length with $120 \mathrm{~cm}$ of this length above the drying chamber. The top of the exhaust cylinder was fitter with a cover to prevent rain and snow from entering.

The data acquisition control system consisted of a personal computer (Tandy 1000, Radio Shack Corporation, Fort Worth, Texas, USA), datalogger (Cole Parmer Cat. No. 60648, Cole Parmer, Vernon Hills, Illinois, USA) and dual temperature controller. The datalogger was connected to the computer through the serial communication port and the dual temperature controller was connected to the computer through the parallel communication port. The sixteen thermocouples (Omega Type-T Cat. No. 06907-00470, Omega Engineering, Laval, Quebec, Canada) were connected to the datalogger. Fifteen of the thermocouples were used to measure the temperature throughout the drying system and the remaining thermocouple was used to measure the chamber temperature. The chamber and duct heaters were connected to the dual temperature controller, so that the temperature of the chamber and drying air could be controlled. The blower motor, rotary motor and stirrer 
motor were also connected to the control system and simultaneously switched on and off daily. The damper motor in the exhaust duct was also hooked to the blower motor to open and close the damper according to the blower operation cycle. There was also a safety switch installed to break the electric current if the duct heater temperature reached $100^{\circ} \mathrm{C}$.

\section{DEVELOPMENT OF AMMONIA SCRUBBER}

The ammonia removal system is shown in Fig. 3. It consisted of a main column $(30 \mathrm{~cm}$ in diameter PVC pipe), three pumps, a reduction cone (from the column to the exhaust vent), a connector (from the manure dryer to the column), five inlets for the sprayer and a $\mathrm{pH}$ probe. On the inside of the column, there was $50 \mathrm{~cm}$ of packing material, a mesh to support the packing material, a cover for the inlet air, and a stainless steel spray nozzle.
The design required the use of three submersible pumps for liquid circulation, filling and draining. The pump used for recirculation (Magnetic Drive Pump, Model S-72008-10, Cole Parmer, Vernon Hills, Illinois, USA) required a substantial head pressure to be able to force the liquid from the base of the tower up to the spray nozzle located in the cone at the top. Water was circulated through the system at a flow rate of $1 \mathrm{~L} / \mathrm{min}$. The other two peristaltic pumps (Watson-Marlow, Model Sci-Q 300, Fisher Scientific, Montreal, Quebec, Canada) were used for filling as it was seen beneficial for the reservoir to be emptied and filled as fast as possible to avoid any down time.

The spray nozzle was made of stainless steel. A stainless steel nozzle was chosen over a much cheaper, but less corrosion proof brass nozzle. The nozzle had a $114^{\circ}$ spray angle so that it could be placed fairly close to the top of the packing material yet still cover the full $30 \mathrm{~cm}$ diameter.

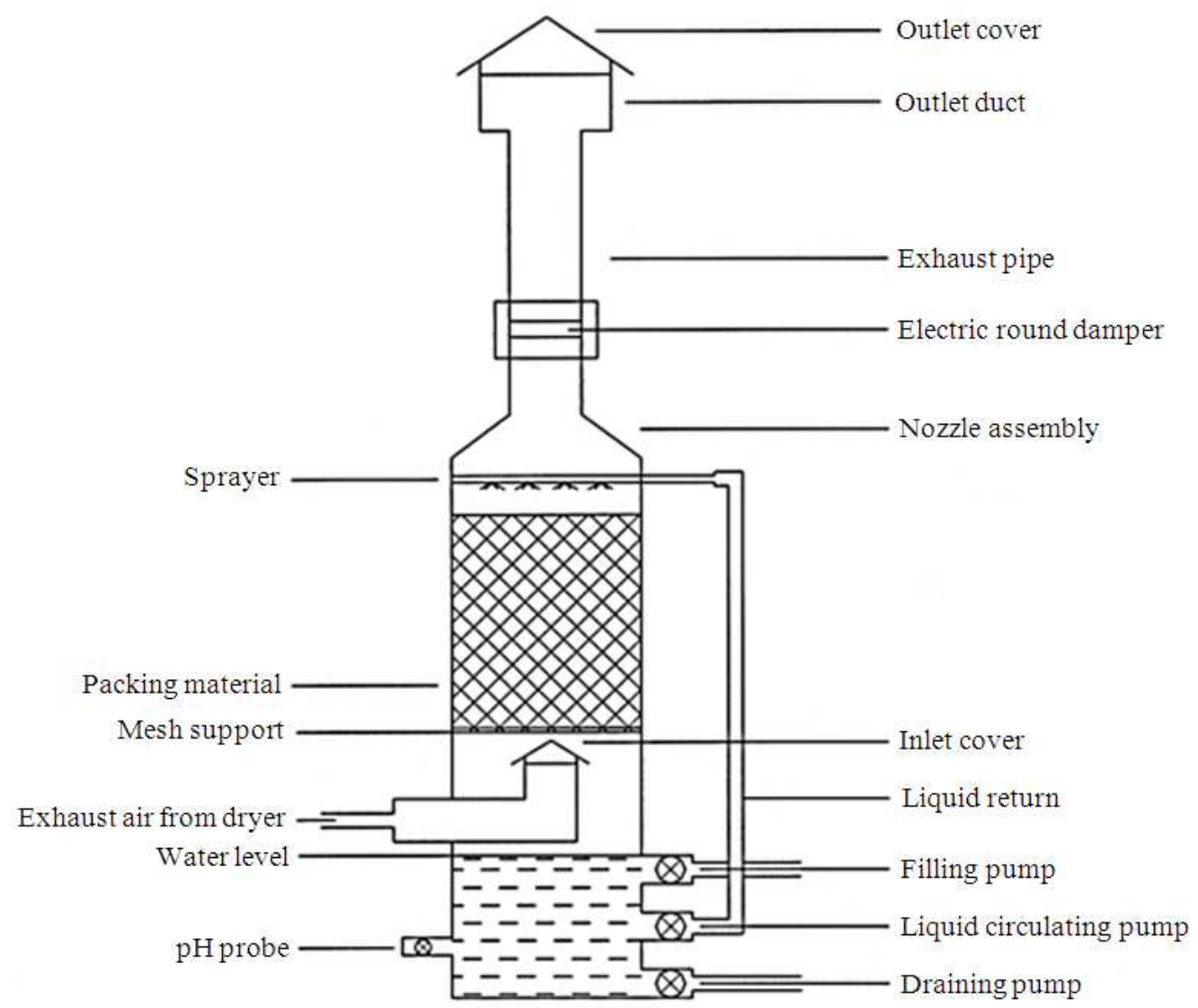

Figure 3. The spray column. 


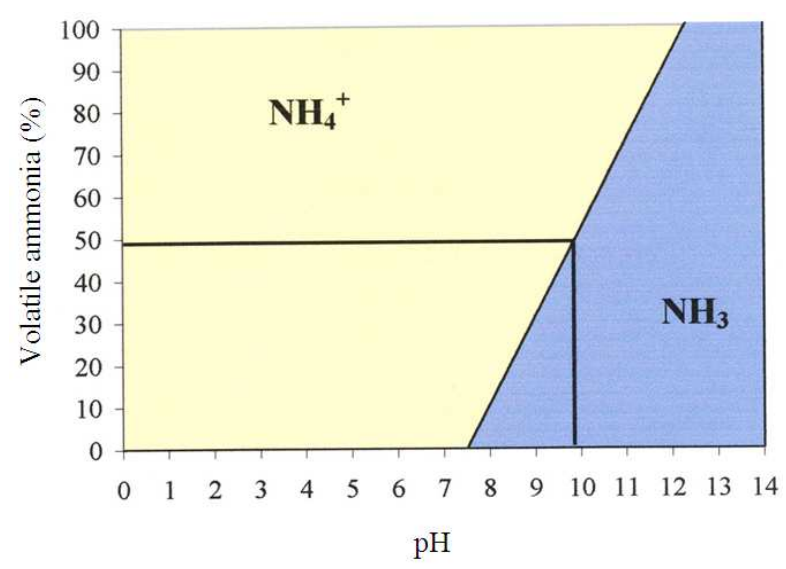

Figure 4: Solubility of ammonia in water at various $\mathrm{pH}$ values

Scrubber water was acidified using $1 \mathrm{~N}$ sulphuric acid, to achieve an initial $\mathrm{pH}$ of 4 . The solubility of ammonia in water is dependent on the water $\mathrm{pH}$. The $\mathrm{pKa}$ value, (the coefficient of dissociation) for ammonia is the $\mathrm{pH}$ at which the compound is $50 \%$ in the volatile form $\left(\mathrm{NH}_{3}\right)$ and $50 \%$ in the ionic form $\left(\mathrm{NH}_{4}{ }^{+}\right)$as shown in Fig 4. Under a pH of 7.25 all ammonia in the exhaust gas can be absorbed by water in the ionic form of $\mathrm{NH}_{4}^{+}$while at the $\mathrm{pH}$ of 9.25 , only $50 \%$ will be in the ionic form $\left(\mathrm{NH}_{4}^{+}\right)$. At a $\mathrm{pH}$ of 11.35 , the water will not absorb any ammonia from the exhaust gas and it will remain in the gaseous form of $\mathrm{NH}_{3}$. Therefore, acidification allowed for greater solubility of ammonia in water by neutralising the weak base created by the ionisation of ammonia to ammonium in water, as shown in Equation 1.

$$
\mathrm{NH}_{3+} \mathrm{H}_{2} \mathrm{O} \rightarrow\left[\mathrm{NH}_{3} \mathrm{OH}\right] \rightarrow \mathrm{NH}_{4}^{+}+\mathrm{OH}^{-}
$$

The packing material used in the column was made from $2.5 \mathrm{~cm}$ diameter PVC pipe cut into small pieces of $2.5 \mathrm{~cm}$ in length, drilled with four holes (Fig. 5). The holes were used to increase surface area for gas/liquid contact and to increase air flow. Using the packing factor for pall rings of $2.5 \mathrm{~cm}$ diameter; it was determined how many lengths of PVC piping were needed.

Since the diameter of the spray tower was $30 \mathrm{~cm}$ and the stack for the dryer was only $10 \mathrm{~cm}$, it was necessary to build a reduction cone that went from 30 $\mathrm{cm}$ to $10 \mathrm{~cm}$. The cone was built by Palmer's Fiberglass, Aylesford, Nova Scotia. The cone was built with overlapping flaps that enabled it to be fit over the column at one end and the $10 \mathrm{~cm}$ stack at the other.

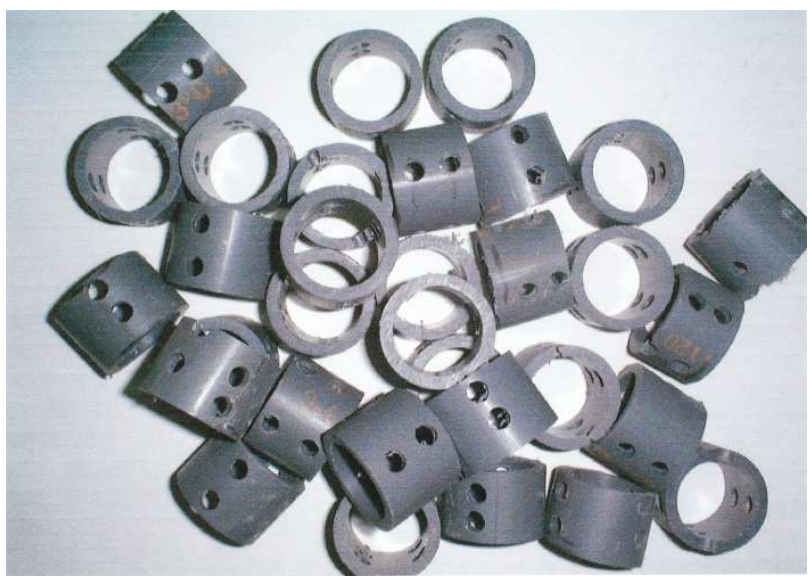

Figure 5. Packing material.

The cone was fitted with the spray nozzle and a Plexiglas window so that the spray pattern could be observed as the system was operating.

The main tube for the tower was fitted with a flat flush cap at one end so that it would hold water and act as a liquid reservoir. A $10 \mathrm{~cm}$ hole was drilled into the tube so that an inlet from the dryer could be fitted. The inlet was made of PVC pipe with an extension and two elbows and was attached to the manure dryer. Another elbow was fitted inside the tube so that the air from the dryer would be directed upwards. On the end of this elbow, a PVC cap was fitted with the proper space allowed for flow. Just above the cap, a Fiberglass mesh was secured in place so that the $50 \mathrm{~cm}$ of packing material above it would not fall into the reservoir. In the packing material region, another Plexiglas window was put in place so that the packing material could also be observed during testing.

The tower was equipped with a $\mathrm{pH}$ probe (GelFilled Combustion Electrode, Fisher 13-620-104 SN1098201, Fisher Scientific Company, Ottawa, Ontario, Canada) and the $\mathrm{pH}$ was measured using a pH meter (Fisher Accument, Model 805 MP, Cat. No. 13-636-805, 115V, 1.08 A, Fisher Scientific Company, Ottawa, Ontario, Canada).

\section{EXPERIMENTAL PROCEDURE}

\subsection{Manure Collection, Storage and Preparation}

Poultry manure was collected from Scotia Poultry Farm, Dartmouth, Nova Scotia, Canada, approximately $15 \mathrm{~km}$ from Halifax. The fresh manure was collected from under the cages in a laying house that housed 36,000 hens. 
Table 3. Some characteristics of the poultry manure used in the study.

\begin{tabular}{lc}
\hline Item & Measured Value \\
\hline Moisture content & $78.4 \%$ \\
Density & $960 \mathrm{~g} / \mathrm{m}^{3}$ \\
Total solids & $215520 \mathrm{mg} / \mathrm{L}$ \\
Volatile solids & $139770 \mathrm{mg} / \mathrm{L}$ \\
Ash & $75750 \mathrm{mg} / \mathrm{L}$ \\
Total chemical oxygen demand & $328500 \mathrm{mg} / \mathrm{L}$ \\
Soluble chemical oxygen demand & $130000 \mathrm{mg} / \mathrm{L}$ \\
Total Kjeldahl nitrogen & $18960 \mathrm{mg} / \mathrm{L}$ \\
Ammonium nitrogen & $9470 \mathrm{mg} / \mathrm{L}$ \\
Calcium & $19760 \mathrm{mg} / \mathrm{L}$ \\
Phosphorus & $5590 \mathrm{mg} / \mathrm{L}$ \\
Potassium & $4140 \mathrm{mg} / \mathrm{L}$ \\
pH & 8.40 \\
\hline
\end{tabular}

The manure was mixed thoroughly with a shovel before collection. There was no treatment of the manure on the farm. The manure was put in wide mouth, clean and dry plastic containers. These containers were sealed and transported to a commercial freezing plant (Associated Freezers, Dartmouth, Nova Scotia, Canada) where they were stored at $-25^{\circ} \mathrm{C}$ until needed. When needed, the containers were transported to the Waste Management Laboratory at Dalhousie University in Halifax, Nova Scotia and kept at room temperature for 48 hours to thaw. Once the manure was thawed it was placed in the drying system. Some characteristics of the poultry manure used in the study are presented in Table 3 .

\subsection{Manure Drying}

The manure drying system was run on the June cycle of solar collector temperature $\left(24\right.$ to $\left.66^{\circ} \mathrm{C}\right)$ at an airflow rate of $0.035 \mathrm{~m}^{3} / \mathrm{s}$ and manure depths of 1,2 and $3 \mathrm{~cm}$. Approximately $7.5,15$ and $22.5 \mathrm{~kg}$ of manure was used. The manure was taken from the sealed container and placed in a pre-weighed bucket. After the proper amount has been weighed out, it was placed into the left door of the dryer. The rotating plate was turned on so that the manure could be spread of to the desired depth all over the table. Once the manure was in place, the stirrer and table motors were turned on and the drying process continued. After about a half hour the computer program was started to enter the time and date. Samples were taken for moisture content, odor and microbial count analysis. The moisture content was determined using the oven drying method described in the ASABE Standards (ASABE, 2009). The odor analysis was performed according to the procedure described by Ghaly and MacDonald (2012a). The microbial counts (total bacterial, yeast and mould, $E$. coli and Salmonella) were performed at the Nova Scotia Research Foundation Corporation.

\subsection{Ammonia Removal}

The recirculating pump in the ammonia scrubbing tower was turned on when the stirrer and table of the drying system were turned on. Once the system started, initial air samples were collected from the tower through the two ports that were installed in the system, one before and one after the tower so that the amount of ammonia before and after could be determined. Sampling continued every hour for the first twelve hours of testing and every six hours for the remainder of the test. Hourly sampling was necessary during the initial testing period because the greatest amount of ammonia would be generated in the first few hours of the drying process. The air samples were then analyzed using a gas chromatograph (5890 Series II, Serial No. 3019A28430, Hewlett Packard, Palo Alto, California, USA). The pH was recorded at the start and then every hour of operation (at the same time as the air samples were taken) using a Fisher Accumet pH meter (Model 805MP, Fisher Scientific Company, Ottawa, Ontario, Canada). The probe was properly calibrated before use and it was installed through a fitting inside the column where it was always in contact with the water.

\section{RESULTS AND DISCUSSION}

\subsection{Drying Process}

\subsubsection{Moisture content}

Table 4 shows the drying times at various manure depths. The results indicated that the $1 \mathrm{~cm}$ deep manure layer dried the fastest, followed by the $2 \mathrm{~cm}$ deep manure layer and the $3 \mathrm{~cm}$ deep layer. The thinner the manure layer, the lower the amount of moisture it contained and consequently the shorted the time it required to drive off the moisture. There are no reports on thin layer drying of animal and poultry wastes. However, the effect of bed depth on the drying rate was investigated for several other materials. Nazghelichi et al. (2010) investigated the effect of bed depth $(30,60$ and $90 \mathrm{~mm})$ on the drying of carrot cubes and found the shortest drying time to be achieved at the $30 \mathrm{~mm}$ depth. Maskan et al. (2002) investigated the effect of layer thickness $(0.71-2.86 \mathrm{~mm})$ on the drying of fruit leather at various temperatures and air velocities and found the optimum depth to be $0.71 \mathrm{~mm}$. Ertekin and Yaldiz (2004) investigated the effect of eggplant slice thickness $(0.63,1.27,2.54 \mathrm{~cm})$ on drying and reported the fastest drying times with the $0.63 \mathrm{~cm}$ thick slices. These results are similar to those obtained in the present study. 
Table 4. Moisture content results (\% wb)

\begin{tabular}{|c|c|c|c|}
\hline \multirow{2}{*}{$\begin{array}{l} \\
\text { Drying } \\
\text { time }(\mathrm{h})\end{array}$} & \multicolumn{3}{|c|}{ Manure Depth $(\mathrm{cm})$} \\
\hline & 1 & 2 & 3 \\
\hline 7 & 74.4 & 74.4 & 74.4 \\
\hline 11 & 62.7 & 70.0 & 71.4 \\
\hline 15 & 17.8 & 62.9 & 67.3 \\
\hline 19 & 6.5 & 53.0 & 63.3 \\
\hline 23 & 6.5 & 50.0 & 61.9 \\
\hline 27 & & 50.1 & 61.9 \\
\hline 31 & & 49.9 & 61.9 \\
\hline 35 & & 39.8 & 57.2 \\
\hline 39 & & 13.5 & 48.1 \\
\hline 43 & & 6.5 & 38.2 \\
\hline 47 & & 6.5 & 35.8 \\
\hline 51 & & & 35.2 \\
\hline 55 & & & 35.3 \\
\hline 59 & & & 26.1 \\
\hline 63 & & & 7.8 \\
\hline 67 & & & 6.5 \\
\hline
\end{tabular}

\subsubsection{Odor}

At the start of each experiment the odor given off near the oven during the drying process was noticeable. However, as the drying process progressed, the presence and offensiveness of the odor decreased with time. The results of the organoleptic test (Fig. 6) showed that both the presence and offensiveness of the odor in the dried poultry manure were reduced by 65.3 and $69.3 \%$ (as compared to that of the fresh poultry manure). The odor present in the dried manure was not found to be offensive $(23.3 \%$ of the panel members described the odor as that of grain, $20 \%$ described it as mouldy/musty, $13.3 \%$ described it as ammonia, $13.3 \%$ described it as sour, fermented, $6.7 \%$ described it as yeast odor and $6.7 \%$ described it as sulphide rotteneggsodor).

Other researchers noticed significant reductions in odor after drying of animal wastes. Welsh et al. (1977) reported a statistically significant decrease in odor after drying swine manure. Zhang et al. (2009) stated that the odor intensity was affected by the initial moisture content. They compared the odor emission in the initial phase of composting of broiler litter with different moisture contents and found that nearly twice as much odor was emitted at the $75 \%$ moisture content compared to $40 \%$ moisture content in the first 24 hours.

\subsubsection{Microbial count}

The results of the microbial analyses are show in in Table 5. High numbers of bacteria $\left(477 \times 10^{7}\right.$ cells $/ g$ manure) and yeast and mould cells ( 2700 cells/g manure) were found in the raw manure. The drying process reduced the number of bacteria by $99.44-99.56 \%$, the number of yeast and mold cells by $88.51-93.70 \%$ and the number of $E$. coli by $99.13 \%-99.56 \%$. Salmonellae were detected in the raw manure but not in the dried manure samples. The results indicated that the thinner the manure layer, the more effective the sterilization of the manure. Chang et al. (1974) reported that the aerobic and anaerobic microbial counts were directly related to the moisture content of dehydrated cage layer samples and inversely related to the dehydration temperature. Kim et al. (2012) studied the thermal inactivation of Salmonellae in broiler litter by dry heat and found that the moisture content affected the survival of Salmonellae in the litter. Watcharasukarn et al. (2009) evaluated the efficiency of pathogen removal by dry heat in dairy manure. Their results indicated that $E$. coli was the most heat susceptible of the three organisms tested (E. coli, E. faecalis, C. perfringes). Elving (2009) observed a $3 \log$ reduction in the E. coli content of dairy manure after using dry heat for $60 \mathrm{~min}$ at $70^{\circ} \mathrm{C}$. The time needed for a $90 \%$ reduction of Salmonellae was $4.3,1.5$ and $0.5 \mathrm{~h}$ at 49,52 and $55^{\circ} \mathrm{C}$, respectively.

\section{$5.1 .4 \mathrm{pH}$}

The manure $\mathrm{pH}$ dripped from 8.4 to about 6.6 during drying as shown in Table 5. The drying depth did not seem to have any significant effects on the $\mathrm{pH}$ of the dried manure. The reduction in the $\mathrm{pH}$ with time was due to the loss of ammonia through the volatization process. Similar results were reported by other researchers. Lopez-Mosquera et al. (2008) observed a drop in $\mathrm{pH}$ (from 8.5 to 7.9 ) when drying poultry manure for pelletizing as fertilizer. Dikinya and Mufwanzala (2010) reviewed the literature and noticed low $\mathrm{pH}$ values for dried poultry manure compared to initial values.

\subsection{Ammonia Removal Process}

\subsection{1pH}

The $\mathrm{pH}$ results are presented in Fig. 7. The $\mathrm{pH}$ of the water rose with time as the water absorbed the ammonia in the exhaust gas from the drying process and then decreased as the manure became dry. This was due to the fact that the air at the end of the drying processes had more $\mathrm{CO}_{2}$ than $\mathrm{NH}_{3}$ and as a result when the water absorbed the $\mathrm{CO}_{2}$ it became acetic again. For the exhaust gas from drying the 2 and $3 \mathrm{~cm}$ manure depths, the $\mathrm{pH}$ of the eater rose and stayed high for much longer periods as the deeper layers took longer times to dry and, therefore, continued to produce $\mathrm{NH}_{3}$ in the exhaust gas. For the $1 \mathrm{~cm}$ deep manure layer the $\mathrm{CO}_{2}$ became the major contributor to the $\mathrm{pH}$ if the water after 10 hours and, therefore, the $\mathrm{pH}$ curve began to descend reaching 5 after 22 hours. 


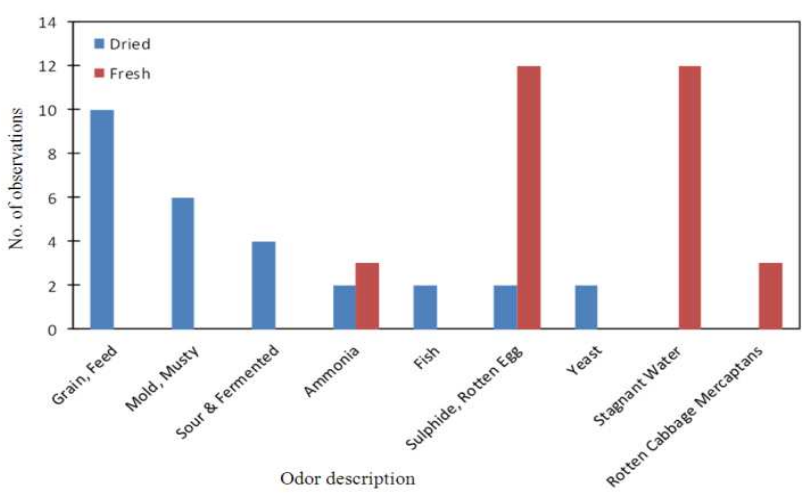

Figure 6. Description of dried poultry manure odor.

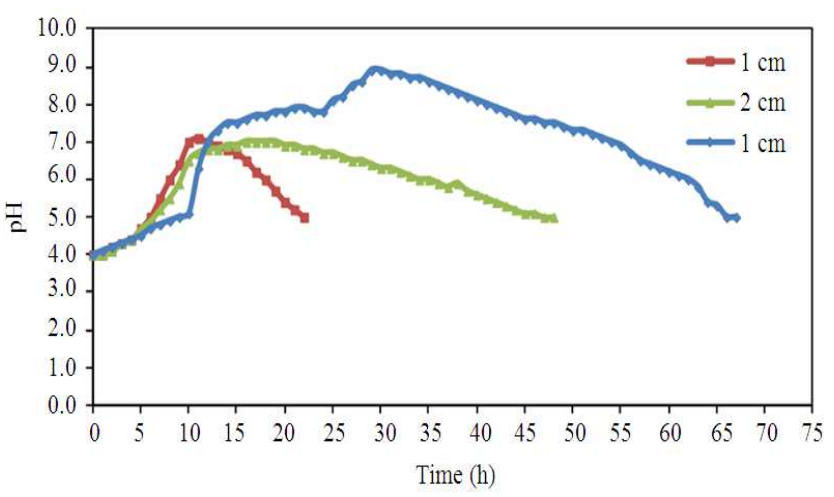

Figure 7. pH variation of scrubber water

Table 5. Average Microbial count in raw and dried poultry manure.

\begin{tabular}{|c|c|c|c|c|c|c|}
\hline Manure & $\begin{array}{l}\text { Drying } \\
\text { Depth }(\mathrm{cm})\end{array}$ & $\begin{array}{l}\text { Bacteria } \\
\left(10^{4} \text { cells/g) }\right.\end{array}$ & $\begin{array}{l}\text { Yeast/Mold } \\
(\text { cells/g) }\end{array}$ & $\begin{array}{l}\text { E. Coli } \\
\left(10^{4} \text { cells } / \mathrm{g}\right)\end{array}$ & $\begin{array}{l}\text { Salmonellae } \\
\text { (presence) }\end{array}$ & $p H$ \\
\hline \multirow[t]{3}{*}{ Dried } & 1 & 2100 & 170 & 10 & $\mathrm{ND}^{\mathrm{b}}$ & 6.7 \\
\hline & 2 & 2900 & 210 & 10 & $\mathrm{ND}^{\mathrm{b}}$ & 6.7 \\
\hline & 3 & 4100 & 310 & 20 & $\mathrm{ND}^{\mathrm{b}}$ & 6.7 \\
\hline Raw & & 477000 & 2700 & 2290 & $\mathrm{PP}^{\mathrm{a}}$ & 8.4 \\
\hline
\end{tabular}

a- Partially Detected

b- Not Detected

The $\mathrm{pH}$ of the water exposed to the exhaust gas from 2 $\mathrm{cm}$ deep manure layer was below 7.35 which is required to keep all the ammonia in the ionic form $\left(\mathrm{NH}_{4}{ }^{+}\right)$, whereas, the $\mathrm{pH}$ of the water exposed to the exhaust gas from drying of the $3 \mathrm{~cm}$ manure layer was above 7.35 most of the time and reached 8.9 indicating that a substantial portion of the ammonia in the exhaust gas passing through the scrubber remained in the gaseous form $\left(\mathrm{NH}_{3}\right)$.

\subsubsection{Ammonia}

The results are shown in Table 6. The results showed $75.73-97.49 \%$ reductions in ammonia levels in the exhaust gas. The manure depth affected the ammonia in the exhaust gas and consequently the ammonia removal efficiency of the scrubber. Although the results showed that the scrubber was effective in removing the ammonia from the exhaust of the manure dryer using acid water, a series of towers would increase the residence time and achieve total removal of ammonia. Byeon et al. (2012) developed a wet scrubbing system for the simultaneous removal of fly ash and ammonia gas and reported ammonia removal rates of $74-86 \%$. Couvert et al. (2007) developed an acidic solution ( $\mathrm{pH}$ of 3 ) based ammonia gas scrubber system and reported ammonia removal efficiencies of $95.0-99.95 \%$ for the two $\mathrm{pH}$ 's respectively. Clippeleir et al. (2012) developed a biofilter for the removal of ammonia from manure storage exhaust gas and reported ammonia removal rates of $60 \%$ at the start up of the biofilter, which increased to $99 \%$ after 60 days of operation.

\subsubsection{Odor}

Odor characteristic of the exhaust gas from the dryer before and after scrubbing are shown in Table 7. The scrubber produced a noticeable reduction in the odor produced by the drying system. The presence of odour and odour offensiveness were reduced by $90 \%$ and $95 \%$, respectively. The odor from the exhaust gas before scrubbing was described by the 30 member panel as ammonia (10), sulfide (6), mercaptans (6), stagnant water (4), yeast (2) and fish (2). The odor in the scrubbed exhaust gas was described as earthy (18), yeast (4), mould (3), fish (2), stagnant water (2) and ammonia (1). Panda et al. (2012) reported an effective removal of process for odors from tanning process gasses by using a dilute boric acid solution to remove ammonia gas from the exhaust. Abu-Khalaf and Haselmann (2012) investigated the effectiveness of odorant removal from a simulated animal waste exhaust gas by wet scrubbing with a dilute acid and noted significant reduction in odor (84.5\%). 
Table 6. Efficiency of the system after six hours of testing (from the GC analysis)

\begin{tabular}{|c|c|c|c|}
\hline \multirow{2}{*}{$\begin{array}{l}\text { Manure } \\
\text { Depth } \\
(\mathrm{cm})\end{array}$} & \multicolumn{2}{|c|}{ Relative Area Under the Peak } & \multirow{2}{*}{$\begin{array}{l}\text { Ammonia } \\
\text { Reduction } \\
(\%)\end{array}$} \\
\hline & $\begin{array}{l}\text { Before } \\
\text { Scrubber }\end{array}$ & $\begin{array}{l}\text { After } \\
\text { Scrubber }\end{array}$ & \\
\hline 1 & 39,92 & 100 & 97.49 \\
\hline 2 & 6,659 & 758 & 88.62 \\
\hline 3 & 12,992 & 3,200 & 75.37 \\
\hline
\end{tabular}

Table 7. Odor rating for exhaust gas from drying $1 \mathrm{~cm}$ manure layer.

\begin{tabular}{lcc}
\multicolumn{1}{c}{ layer. } & $\begin{array}{c}\text { Before } \\
\text { Scrubbing* }\end{array}$ & $\begin{array}{c}\text { After } \\
\text { Scrubbing }\end{array}$ \\
\hline Presence & 10 & $1.0 \pm 0.75$ \\
Offensiveness & 10 & $0.5 \pm 0.25$ \\
Description & & \\
$\quad$ Mold \& Fermented & 2 & 3 \\
$\quad$ Yeast & - & 4 \\
Earth & 2 & 18 \\
Fish & - & 2 \\
Ammonia & 10 & 1 \\
Sulfide, Rotten Egg & 6 & - \\
$\quad$ Stagnant Water & 4 & 2 \\
$\quad$ Mercaptans, Rotten Cabbage & 6 & - \\
\hline
\end{tabular}

Total of 30 observations

\section{CONCLUSION}

The aim of this study was to develop an ammonia removal system for a poultry manure drying system. The thin layer drying of poultry manure in 1-3 cm thick layers resulted in effective sterilization, with the removal of $99.44-99.56 \%$ of total bacterial count, 88.51-93.705 of yeast and mold cells, 99.13-99.565 of E.coli cells, and complete removal of Salmonellae. The drying of poultry manure resulted in a large loss of nitrogen, through ammonia loss in the exhaust gasses. The use of a water scrubber resulted in a $75-99 \%$ removal of ammonia gas from the exhaust gases. The absorption of ammonia into the scrubber's water resulted in an increase in $\mathrm{pH}$, which subsequently fell as the drying process finished, and ammonia emission decreased. The heated air drying of poultry manure, with the use of an ammonia removal system proved effective in reducing the odor intensity and offensiveness of the poultry manure, resulting in increased air quality.

\section{ACKNOWLEDGEMENT}

This research was funded by the Natural Science and Engineering Research Council (NSERC) of Canada.

\section{REFERENCES}

Abu-Khalaf, N. and K.F. Haselmann, 2012. Characterization of odorants in an air wet scrubber using Direct Aqueous Injection-GaschromatographyMass Spectrometry (DAI-GC-MS) and Soild Phase Extraction (SPE-GC). American Journal of Environmental Engineering, 2: 56-68. DOI: 10.5923/j.ajee.20120203.04.

Alam, M.S., M.J. Khan, M.A. Akber and M. Kamruzzaman, 2008. Broiler litter and layer manure as the diet of growing bull calves. The Bangladesh Veterinarian, 25: 62-67. DOI: 10.3329/bvet.v25i2.4619.

Anderson, N., R. Strader and C. Davidson, 2003. Airbone reduced nitrogen:ammonia emissions from agriculture and other sources. Environment Internationsl, 29: 277-286.

ASABE, 2009. Standards American Society of Agricultural and Biological Engineers. Saint Joseph, MI. USA. ISBN: 87551187.

ASTDR, 2002. Toxicologiclal profile for ammonia.

Bernhart, M. and O.O. Fasina, 2009. Moisture effect on the storage, handling and flow properties of poultry litter. Waste Management, 29: 1392-1398. DOI: 10.1016/j.wasman.2008.09.005

Byeon, S.H., B.K. Lee and B.R. Mohan, 2012. Removal of ammonia and particulate matter using a turbulent wet scrubbing system. Seperation and Purification Technology, Article in Press, DOI: 10.1016/j.seppur.2012.07.014.

Chang, T.S., D. Dorn and H.C. Zindel, 1974. Stability of poultry anaphage. Poultry Science, 5: 2221-2224. DOI: $10.3382 /$ ps.0532221.

Chung, Y.C., C. Huang and C.P. Tseng, 1997. Biotreatment of ammonia from air by an immobilized Arthrobacter oxydans CH8 biofilter. Biotechnology Progress, 13: 794-798. DOI: 10.1021/bp970065e.

Clippeleir, H. D., E. Courtens, M. Mosquera, S.E. Vlaeminck and B.F. Smets et al., 2012. Efficient total nitrogen removal in an ammonia gas biofilter through high-rate OLAND. Environmental Science and Technology, 46: 8826-8833. DOI: 10.1021/es301717b.

Couvert, A., C. Sanchez, A. Laplanche and C. Renner, 2007. Scrubbing intensification for sulphur and ammonia compounds removal. Chemosphere, 70: $1510-1517$.

DOI: 10.1016/j.chemosphere.2007.08.020. 
Dikinya, O. and N. Mufwanzala, 2010. Chicken manureenhanced soil fertility and productivity: Effects of application rates. Journal of Soil Science and Environmental Management, 1: 46-54. http://www.academicjournals.org/jssem

Elving, J., 2009. Pathogenic inactivation and regrowth in organic waste during biological treatment. Licentiate thesis. Swedish University of Agricultural Sciences, Uppsala, Sweeden.

Ertekin, C. and O. Yaldiz, 2004. Drying of eggplant and selection of a suitable thin layer drying model. Journal of Food Engineering, 63: 349-359. DOI: 10.1016/j.jfoodeng.2003.08.007.

Ghaly, A.E. and K.N. MacDonald, 2012a. An effective passive solar dryer for thin layer drying of poultry manure. American Journal of Engineering and Applies Sciences, 5: 136-150. DOI: 10.38.44/ajaeassp.2012.136.150.

Ghaly, A.E. and K.N. MacDonald, 2012b. Drying of poultry manure for use as animal feed. American Journal of Agricultural and Biological Sciences, 7: 239-254. DOI: 10.3844/ajabssp.2012.239.254.

Ghaly, A.E. and M. Al-Hattab, 2012. An innovative farm scale biogas/composting facility for a sustainable medium size dairy farm. American Journal of Agricultural and Biological Sciences, 7: 1-16. DOI: 10.3844/ajabssp.2012.1.16.

Heinsohn, R.J., K.E. Noll, A.J. Buonicore, D.C. Cooper and S.J. Ergas, 2000. Control of Gaseous Pollutants. In: Air Pollution Engineering Manual, Davis, W.T. (Ed.), John Wiley and Sons, New York, pp: 22-65. ISBN: 0471333336

Kim, J., J. Diao, M.W. Shepherd Jr., R. Singh and S.D. Heringa et al., 2012. Validating thermal inactivation of Salmonella spp. in fresh and aged chicken litter. Applied and Environmental Microbiology, 78: 1302-1307. DOI: 10.1128/AEM.06671-11

Lopez-Mosquera, M.E., F. Cabalerio, M.J. Sainz, A. Lopes- Fabal and E. Carral, 2008. Fertilizing value of broiler litter: Effects of drying and pelletizing. Bioresource Technology, 99: 5626-5633. DOI: 10.1016/j.biotech.2007.10.034.
Maskan, A., S. Kaya and M., Maskan, 2002. Hot air and sun drying of grape leather (pestil). Journal of Food Engineering, 54: 81-88. DOI: 10.10 16/S02608774(01)00188-1.

Nazghelichi, T., M.H. Kianmehr and M. Aghbashlo, 2010. Thermodynamic analysis of fluidized bed drying of carrot cubes. Energy, 35: 4679-4684. DOI: 10.1016/j.energy.2010.09.036.

Panda, R.C., C.L. Rai, V. Sivakumar and A.B. Mandal, 2012. Odour removal in leather tannery. Advances in Chemical Engineering and Science, 2: 199-203. DOI: 10.4236/aces.2012.22024.

Seidel, A., 2004. Kirk-Othmer Encyclopedia of Chemical Technology, 5th Edn., John Wiley and Sons, Inc., New Jersey. pp: 678-710.

Thomas, J.W., Y.Y.P. Tinnimitt and H.C. Zindel, 1972. Dehydrated poultry waste as a feed for milking cows and growing sheep. Journal of Dairy Science, 55: 261-1265. DOI: 10.3168/jds.S0022-0302(72)85659-5.

Watcharasukarn, M., P. Kaparaju, J.P. Steyer, K.A. Krogfelt and I. Angelidaki, 2009. Screening Escherichia coli, Enterococcus faecalis, and Clostridium perfringens as indicator organisms in evaluating pathogen-reducing capacity in biogasplants. Environmental Microbiology, 58: 22130. DOI: $10.1007 / \mathrm{s} 00248-009-9497-9$.

Welsh, F.W., D.D. Schulte, E.J. Kroeker and H.M. Lapp, 1977. The effect of anaerobic digestion upon swine manure odors. Canadian Agricultural Engineering, 19: 122-126. http://bioeng.ca/docs/journal/19/19_2_122_raw.pdf

Zhang, W., A.K. Lau and Z.S. Wen, 2009. Preventive control of odor emissions through manipulation of operational parameters during the active phase of composting. Journal of Environmental Science and Health, Part B: Pesticides, Food Contaminants, and Agricultural Wastes, 44: 496-505. DOI: 10.1080/03601230902935451. 